\title{
Total dissolved carbohydrates in an enclosure experiment with unialgal Skeletonema costatum culture
}

\author{
K. Eberlein ${ }^{1}$, U. H. Brockmann ${ }^{1}$, K. D. Hammer ${ }^{1}$, G. Kattner ${ }^{1}$ and M. Laake ${ }^{2}$ \\ ${ }^{1}$ Institut für Organische Chemie und Biochemie, SFB 94, Universität Hamburg, Martin-Luther-King-Platz 6, \\ D-2000 Hamburg 13, Federal Republic of Germany \\ ${ }^{2}$ Institute of Microbiology and Plant Physiology, University of Bergen, Allégatan 70, N-5014 Bergen-Universitetet, Norway
}

\begin{abstract}
In a southem Norwegian fjord (Rosfjord) during POSER a plastic enclosure ( $1 \mathrm{~m} \varnothing, 20 \mathrm{~m}$ depth) was filled with filtered fjord water enriched with inorganic nutrients and inoculated with a monoculture of Skeletonema costatum. The enclosure was exposed to fjord conditions from March 18 to April 5, 1979. Pre-filtration had removed ca. $80 \%$ of the bacterial population in the fjord water. Following a short lag phase, bacteria grew exponentially. After consumption of nitrogen-containing organic substances, dissolved carbohydrates were the main energy source; however, bacterial numbers did not increase further, probably due to grazing by nanoflagellates. In spite of sub optimal light and temperature conditions, $S$. costatum reached cell densities as high as $35 \cdot 10^{6} \mathrm{dm}^{-3}$ at $3 \mathrm{~m}$ water depth, since competing algae and grazing zooplankton were missing in the enclosure. The diatoms grew exponentially, with a division rate of $\mu=0.6 \mathrm{~d}^{-1}$ and reached the stationary phase after $16 \mathrm{~d}$, when inorganic nutrients were exhausted. During growth of $S$. costatum relatively high amounts of carbohydrates were released. Maximum concentrations followed the exponential phase, but highest release rates per cell -2.0 pmoles glucose equivalents cell ${ }^{-1} \mathrm{~d}^{-1}-$ were reached immediately after inoculation. Measurements at $3 \mathrm{~h}$ intervals at the end of the experiment showed that concentrations and therefore release activities varied abruptly within a few hours. Main release occurred from noon to midnight. Not all dissolved carbohydrates were immediately taken up by heterotrophic organisms, part of them could not be utilized, others only after adaptation or succession of bacteria. During the experiment, the proportion of the labile fraction to the total dissolved carbohydrates varied greatly.
\end{abstract}

\section{INTRODUCTION}

As is well known, healthy phytoplankters release considerable amounts of photosynthetic products during development (Lewin, 1956; Prager et al., 1959; Guillard and Hellebust, 1971; Ignatiades and Fogg, 1973; Aaronson, 1978; Sharp, 1978; Mague et al., 1980). Carbohydrates are one of the main components of the organic substances released (Degens, 1970; Handa, 1970; Hellebust, 1974; Bolze and Soeder, 1978). Possibly, they play an important role in aquatic food chains.

An objective of this work was a detailed investigation of the release of dissolved carbohydrates during phytoplankton development as a function of different growth phases. Because of horizontal advection, measurements in the open sea do not seem an appropriate means for such investigations. Enclosures containing unfiltered sea water do not provide much better conditions, since normally in such experiments many plankters develop simultaneously (Brockmann et al., 1977 b, 1979; Kattner et al., 1983). A bloom of one particular species is achieved more easily when sea water is filtered, enriched with inorganic nutrients and inoculated with a monoculture of phytoplankton. Such experiments were carried out in large plastic enclosures (tanks) during POSER in a south Norwegian fjord in 1979 (Brockmann et al., 1983). For inoculation, diatom species which dominated in the fjord during the experiment were precultured (Jahnke et al., 1983). This paper reports results of a tank experiment with Skeletonema costatum. Inorganic nutrients were added in relatively small quantities, equivalent to about maximum concentrations in the fjord. In this 
way, results for carbohydrate release were obtained which occurred under nearly natural conditions. Since monocultures in our tanks cannot be kept axenic, prefiltration of the water was carried out in such a way that natural bacteria and other microorganisms as nanoflagellates were not removed completely.

Many investigators have attempted to demonstrate stimulation of bacterial growth by algal extracellular products, of which carbohydrates comprise the substances of most interest (for review see Bell and Sakshaug, 1980); possible antibiotic effects have remained less studied (Sieburth, 1968). However, compared to grazing by protozoans, antibiosis is now considered to be of little importance for the removal of coliform bacteria in estuarine waters (Enzinger and Cooper, 1976). Generally, stimulation of bacterial numbers and production in the productive season in temperate waters is well documented (e.g. Hagström et al., 1979). Such stimulation is related to algal extracellular release during growth, as well as to substances released during senescence (Sieburth, 1979). Thus, an additional objective of this work was the investigation of the growth of heterotrophic bacteria during the developing diatom bloom.

\section{METHODS}

In the Rosfjord a plastic tank ( $1 \mathrm{~m} \varnothing, 20 \mathrm{~m}$ depth) was filled on March 16, 1979, with plate-filtered fjord water of $29.6 \%$ salinity and exposed from March 18 to April 5 (Brockmann et al., 1983). Plate filters (Type 2/1250) were obtained from Seitz (Bad Kreuznach, F.R.G.); they hat a pore size of approximately $0.2 \mu \mathrm{m}$. By enrichment of the water with inorganic nutrients the following concentrations were obtained: $11.2 \mu \mathrm{g}$ at nitrate- $\mathrm{N} \mathrm{dm}{ }^{-3}, 0.8 \mu \mathrm{g}$ at o-phosphate-P dm ${ }^{-3}$, and 7.5 $\mu \mathrm{g}$ at silicate-Si $\mathrm{dm}^{-3}$. Initial ammonia concentrations were approximately $1 \mu \mathrm{g}$ at ammonia- $\mathrm{N} \mathrm{dm}{ }^{-3}$. The water was inoculated with a monoculture of Skeletonema costatum on March 18 (Jahnke et al., 1983). On March 21, the tank was re-inoculated with 5 isolates of bacteria for ecological studies (Dahle and Laake, 1982).

Samples were taken at $0,3,10$ and $15 \mathrm{~m}$ depth (Brockmann and Hentzschel, 1983; Brockmann et al., 1983). To count of colony forming units (CFU), triplicate $0.1 \mathrm{ml}$ spread plates were prepared on a pepton trypton, yeast extract medium $\left(0.5 \mathrm{~g} \mathrm{dm}^{-3}\right.$ of each in $1.5 \%$ sea water agar; Dahle and Laake, 1982) and incubated at $10^{\circ} \mathrm{C}$ for $21 \mathrm{~d}$. Samples of $10 \mathrm{ml}$ were preserved with neutralized formaldehyde $(2 \%$ final concentration) until prepared for acridine orange total counts (AOTC) by epifluorescence microscopy (Hobbie et al., 1977). For diatom counting (Wild inverted micro- scope), samples were fixed with neutralized formalin. Particles were counted immediately after sampling with a Coulter Counter TA II in raw water samples.

For chemical analyses, filtration was performed under constant vacuum ( 0.5 at) using GF/C (Whatman) glass-fibre filters which are known to have a retention ability of $1.2 \mu \mathrm{m}$. Nutrient measurements were carried out immediately after sampling and filtration. Samples for carbohydrate determination were fixed with $3 \mathrm{ml}$ $\mathrm{dm}^{-3}$ of a $3.5 \%(\mathrm{w} / \mathrm{w}) \mathrm{HgCl}_{2}$-solution and stored at about $4^{\circ} \mathrm{C}$.

Nutrients were measured with a Technicon AutoAnalyzer II, using methods for sea-water determinations recommended by Technicon (Methods No. 154-71 W, 155-71 W, 158-71 W, 186-72 W). They correspond to standardized methods of the Baltic countries (Carlberg, 1972). Nitrate plus nitrite, ammonia, ortho-phosphate and silicate were measured simultaneously from the same sample, using synthetic sea water (Technicon $158-71 \mathrm{~W}$ ) as wash water. During the entire experiment the same stock standard which was preserved with chloroform (1 $\left.\mathrm{cm}^{3} \mathrm{dm}^{-3}\right)$ was used. Working standards were prepared fresh daily with synthetic sea water as diluent. A low sampling frequency of 10 to 30 samples $h^{-1}$ and a relatively long wash time were used, since base-lines sometimes drifted strongly, in spite of use of low-drift-phototubes and low-drift-amplifiers in the colorimeters. Between different samples many working standards were measured for calibration. Since ammonia in the air interfered with measurements of this parameter, sample cups were closed with a very thin membrane of Parafilm (Serva) which could be penetrated by the sharpened sampler needle.

Total dissolved carbohydrates were also determined with a Technicon AutoAnalyzer II using the L-tryptophan/sulfuric acid method I of Eberlein and Hammer (1980). Concentrations of interfering nitrate were measured with the conventional AutoAnalyzer method. By running nitrate standards for additional calibration of the carbohydrate channel it was possible to determine the nitrate reading which had to be substracted from the total reading. Since glucose was used for calibration of the carbohydrate determinations, concentrations were measured as glucose equivalents (Glc Eq).

\section{RESULTS}

Due to several influxes of cold, less haline water into the fjord (Brockmann et al., 1981) temperatures in the upper water layer and in the tank reached only 1 to $3^{\circ} \mathrm{C}$ during the entire tank experiment; the deeper water in the fjord was warmer $\left(2\right.$ to $6^{\circ} \mathrm{C}$ ) (Brockmann et al., 1981). 
Fig. 1. Skeletonema costatum. Development of cell numbers at different depths in the enclosure (semi-logarithmic representation)
Fig. 2. Acridine orange total counts (AOTC) of bacteria and colony forming units (CFU) at different depths in the Skeletonema costatum tank (semilogarithmic representation)

\section{Growth of Skeletonema costatum}

After adding Skeletonema costatum to the filtered and enclosed water on March 18, 1979 exponential growth started immediately (Fig. 1); initial density was 50,000 cells $\mathrm{dm}^{-3}$. Daily cell division rate $(\mu)$ was as low as 0.6 and remained quite constant with the exception of the drop on April 1 to 2 at $3 \mathrm{~m}$. Because of the low division rate, the exponential growth phase at $3 \mathrm{~m}$ lasted $16 \mathrm{~d}$; the stationary phase was reached on April 3,1979 .

Diatom development at $10 \mathrm{~m}$ paralleled that at $3 \mathrm{~m}$, but was delayed by $2 \mathrm{~d}$. The stationary phase was
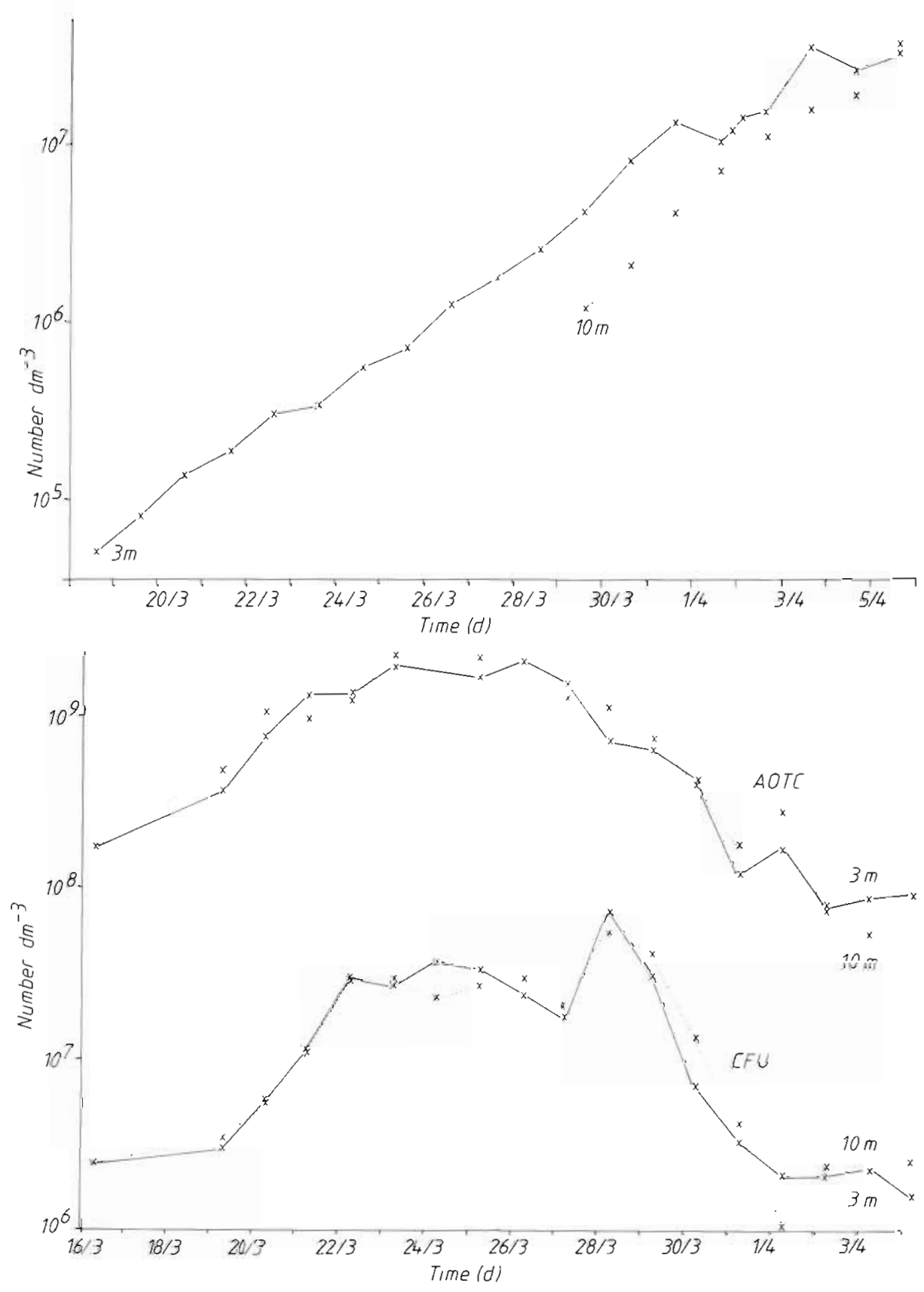

reached at $10 \mathrm{~m}$ at the end of the experiment on April 5. Both, at 3 and $10 \mathrm{~m}$, division rates were equally high after March 29, except for the drop on April 1 to 2.

\section{Development of heterotrophic microorganisms}

A comparison of acridine orange total counts (AOTC) of fjord and enclosure samples revealed that the pre-filtration removed ca. $80 \%$ of the bacterial population. After $3 \mathrm{~d}$ (possibly including a 1 to $2 \mathrm{~d}$ lag phase) the bacteria in the enclosure grew exponentially for 4 d until March 23 (Fig. 2). The 5 strains used 
for re-inoculation of the tank on March 21 comprised initially no more than $10 \%$ of AOTC which may be considered insignificant in this context. The maximum specific growth rate for the AOTC population was $\mu=$

\section{Consumption of inorganic nutrients}

Except for ammonia, decreasing rates of nutrients were considered as uptake rates, since uptake proces-

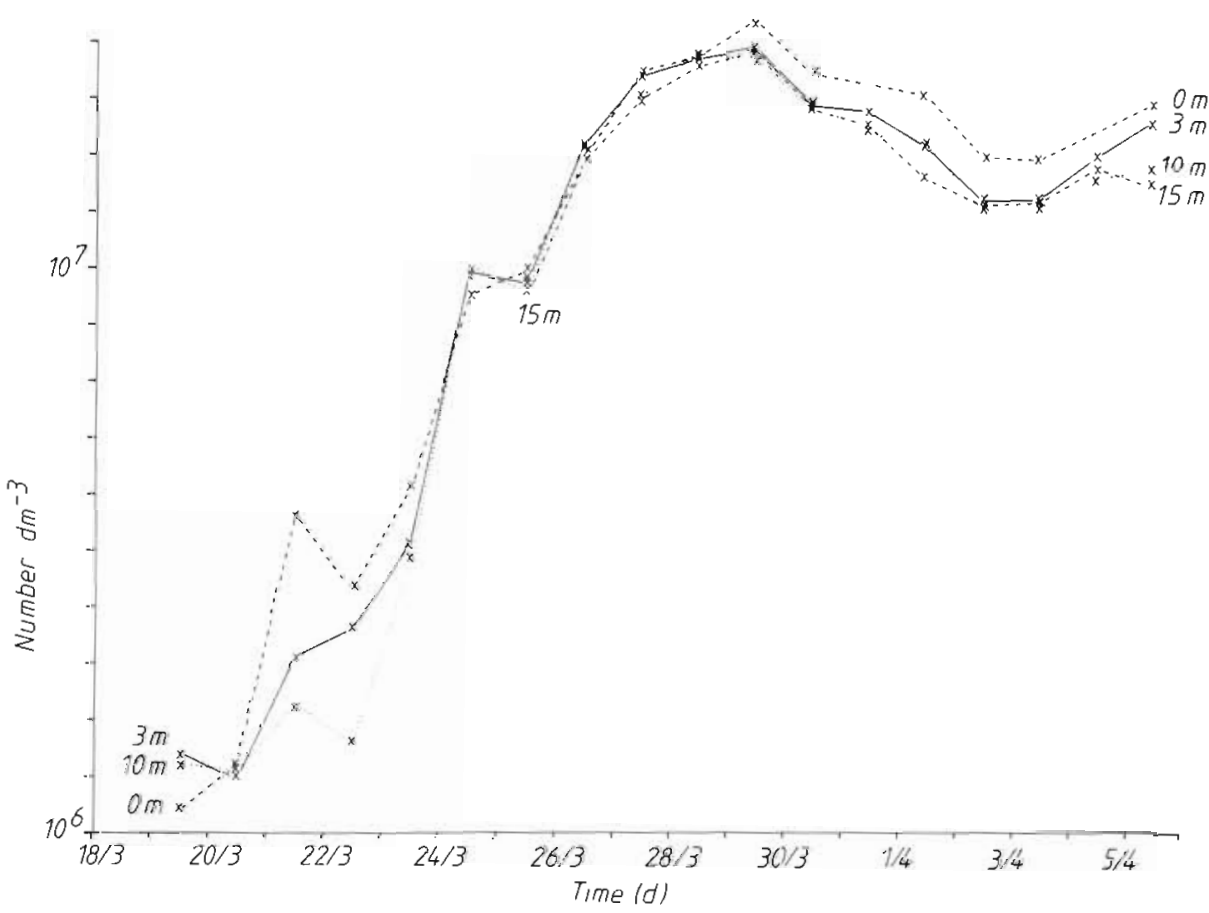

Fig. 3. Coulter Counter measurements of 1.5 to $3 \mu \mathrm{m}$ particles at different depths in the Skeletonema tank (semi-logarithmic representation)

$0.62 \mathrm{~d}^{-1}$; for colony forming units (CFU) of organotrophic bacteria it was $\mu=1.4 \mathrm{~d}^{-1}$. On March 22 to 23 a steady state developed; it lasted for about $6 \mathrm{~d}$ and was terminated by a rapid decline in both the AOTC and the CFU population to ca. $5 \%$ of the maximum level. At both sampling depths $(3$ and $10 \mathrm{~m})$ bacteria developed in a similar way (Fig. 2); temperatures also showed nearly no differences at these depths (Brockmann et al., 1981).

Coulter Counter measurements revealed that, in addition to bacteria and inoculated diatoms, particles with a size of 1.5 to $3 \mu \mathrm{m}$ had increased in number. Distinction was possible because of different sizes and development of these particles from bacteria and diatoms. Increase of 1.5 to $3 \mu \mathrm{m}$ particles was parallel at all 4 sampling depths; stratification could not be detected (Fig. 3). From March 24 to 29, a large increase was observed, interrupted by a decrease on March 25. On March 29, maximum values of about $25 \cdot 10^{6}$ particles $\mathrm{dm}^{-3}$ were measured. The period of fast growth of the 1.5 to $3 \mu \mathrm{m}$ fraction coincided with the period of continuously high bacterial numbers. Nearly simultaneous with the beginning of decreasing bacterial numbers on March 30, a distinct decrease in the 1.5 to 3 $\mu \mathrm{m}$ particle fraction was observed. This fraction increased again slightly at the end of the experiment on April 4.

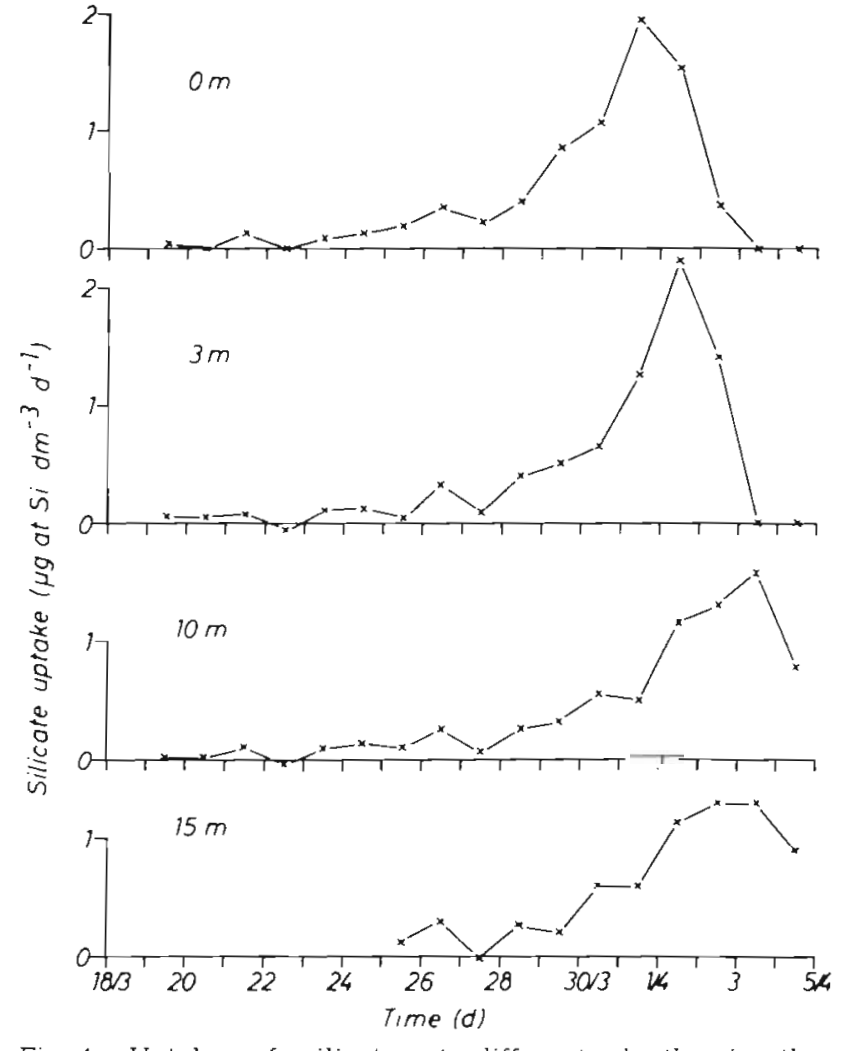

Fig. 4. Uptake of silicate at different depths in the Skeletonema tank; daily means 


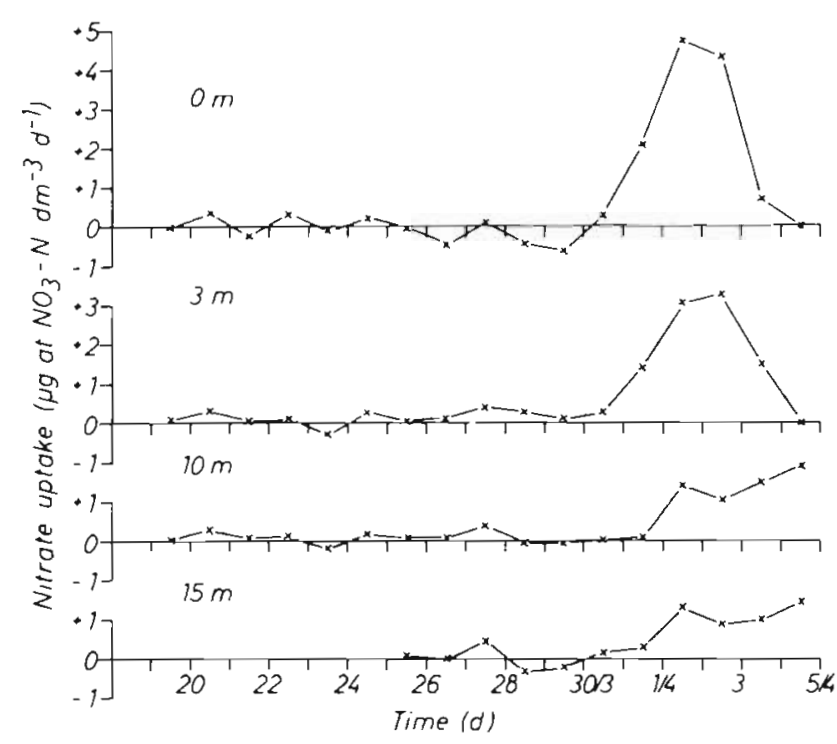

Fig. 5. Uptake of nitrate plus nitrite at different depths in the Skeletonema tank; daily means
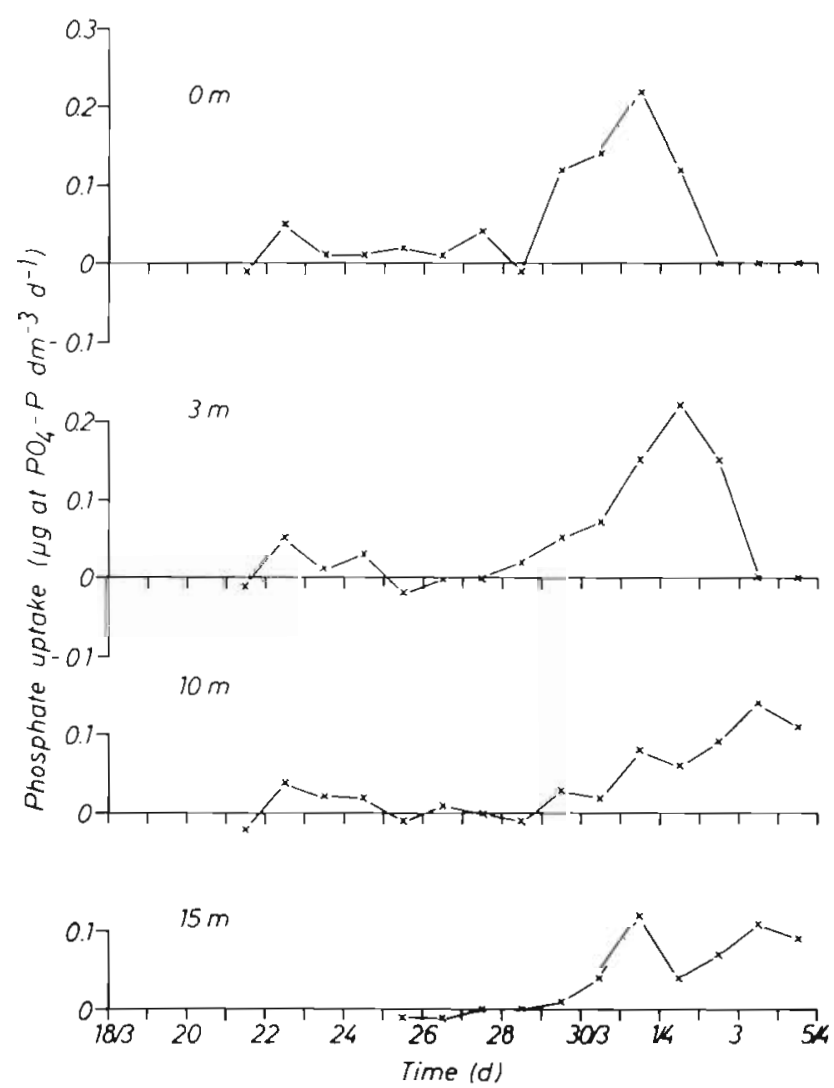

Fig. 6. Uptake of ortho-phosphate at different depths in the Skeletonema tank; daily means

ses were dominating, especially in the case of silicate and nitrate. The daily uptake in the enclosure is shown for 4 different sampling depths in Fig. 4 to 6. At the beginning of the experiment the water was enriched with nutrients to nearly the level of winter concentrations in this area. Uptake of silicate and phosphate was not evident at the surface until March 29; nitrate uptake started $2 \mathrm{~d}$ later. Strong nutrient uptake began later at lower sampling depths.

The uptake of the 3 inorganic nutrients showed a clear maximum at the surface and at $3 \mathrm{~m}$. Maxima were reached first at the surface, later at increasing depth. Maxima of phosphate uptake coincided with those of silicate uptake; nitrate-uptake maxima were reached 1 d later.

Phosphate, nitrate and silicate were depleted early at 0 and $3 \mathrm{~m}$ depths, whereas at 10 and $15 \mathrm{~m}$ nutrients

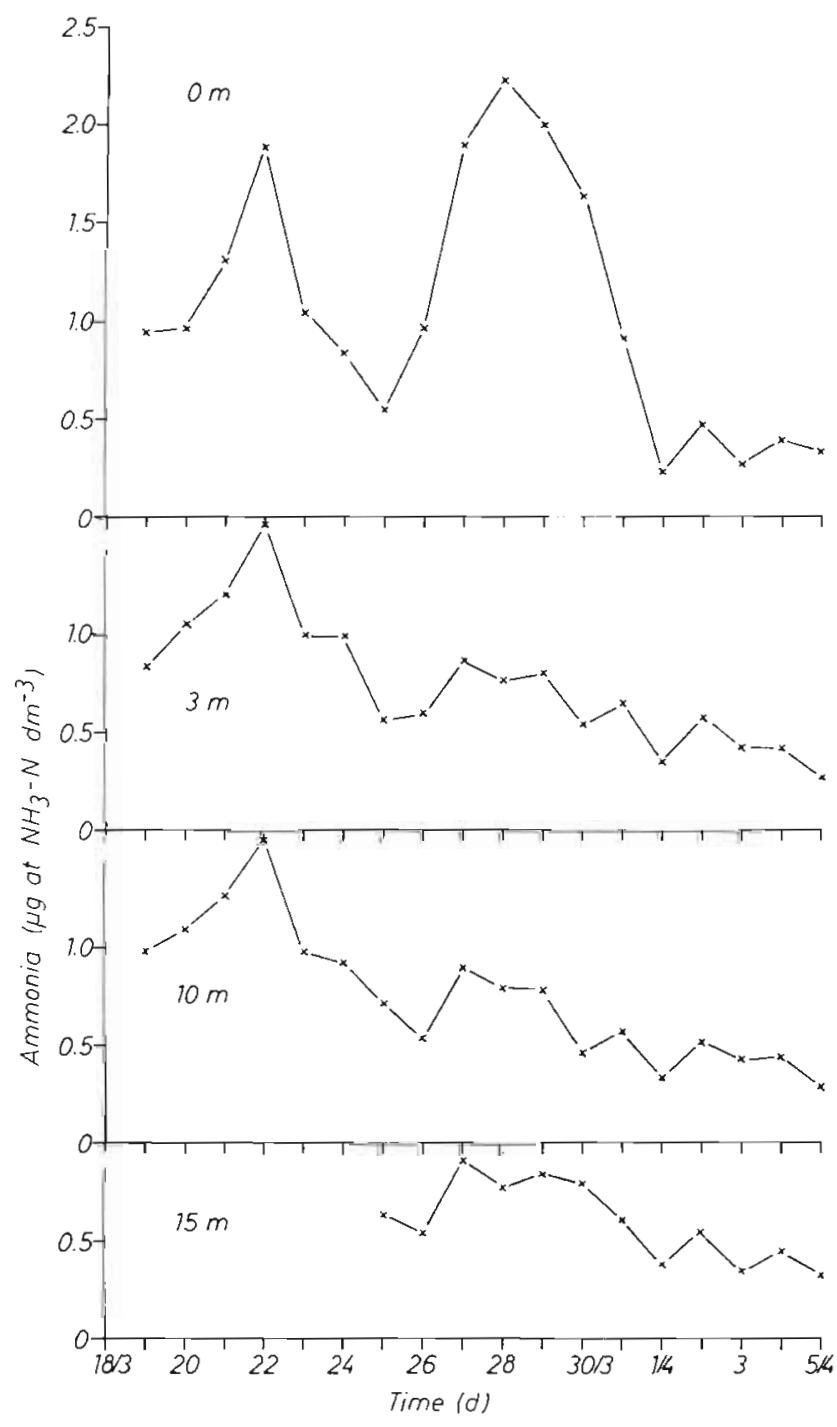

Fig. 7. Daily means of ammonia concentrations at different depths in the Skeletonema tank

were still available at the end of the experiment. At the surface, phosphate was exhausted by April 2, while silicate and nitrate were fully consumed 1 and $2 \mathrm{~d}$ 
later, respectively. Nutrient depletion was delayed with increasing sample depth.

Since ammonia exhibited high concentration increases repeatedly, it was apparently not only taken up, but also released in relatively large amounts (Fig. 7). At all depths concentration maxima occurred near March 22 and March 28. The second maximum was much higher and more distinct at the surface than in the deeper water.

\section{Concentrations of total dissolved carbohydrates}

At the beginning of the experiment high concentrations of total dissolved carbohydrates (Fig. 8) were found in the $0.2 \mu \mathrm{m}$ plate-filtered and enclosed water after sampling and filtration through glass-fibre filters (GF/C-Whatman, $1.2 \mu \mathrm{m}$ retention ability). The same high concentrations of about $2.3 \mu$ moles Glc Eq dm ${ }^{-3}$ were also measured in parallel samples additionally filtered through $0.1 \mu \mathrm{m}$ membrane filters (Sartorius SM 11309). Carbohydrate concentrations remained high for $6 \mathrm{~d}$, but decreased rapidly on March 23 and 24. The decrease occurred at the same time and to the same large amount at all depths (Fig. 9). After the rapid decrease, except for small fluctuations, carbohydrate concentrations remained in the low range of about 1.3 umoles Glc Eq dm ${ }^{-3}$ until April 2 (Fig. 8). From March 18 to April 1 measurements of parallel samples, filtered through $0.1 \mu \mathrm{m}$ filters as above, yielded sirnilar concentrations as samples filtered only through $1.2 \mu \mathrm{m}$ filters.

After April 2, extremely high carbohydrate concen- trations were detected in single samples. Minimum values only increased relatively little from 1.3 to 1.8 $\mu$ moles Glc Eq $\mathrm{dm}^{-3}$ during this time. Concentration maxima on April 4 were much lower than those on April 3 and 5 .

A detailed study of the carbohydrate concentrations at $3 \mathrm{~m}$ for the first $6 \mathrm{~d}$ of the experiment (Fig. 8) shows that, for the relatively small fluctuations during this time, a daily cycle can be detected. The highest concentrations of 2.3 to 2.5 moles Glc Eq dm ${ }^{-3}$ appeared at about noon, while at night a decrease to a value of about 2.2 moles Glc Eq dm $\mathrm{dm}^{-3}$ took place. A daily cycle was calculated by averaging decrease and increase rates at $6 \mathrm{~h}$ intervals over the first $6 \mathrm{~d}$ (Fig. 10). Due to a reduced sampling frequency at other depths the daily cycle of carbohydrate release could only be demonstrated at the depth of $3 \mathrm{~m}$. The violent fluctuations in April (Fig. 8) did not run on the same, but on a similar cycle as those during the first $6 \mathrm{~d}$ of the experiment.

Whereas mean carbohydrate concentrations at all depths ran nearly parallel until April 1, this was not the case for the period from April 2 to 5 (Fig. 11). At $15 \mathrm{~m}$ no significant carbohydrate maxima were observed, while at $10 \mathrm{~m}$ they were highest. Also the peak patterns showed clear differences at different depths. Although carbohydrates were measured every $3 \mathrm{~h}$ at the end of the experiment, most peaks, especially at 10 $\mathrm{m}$, are represented by only 1 measurement. A common feature of all sampling depths was that also during this period the highest carbohydrate concentrations appeared mainly during daylight, especially in the afternoon.

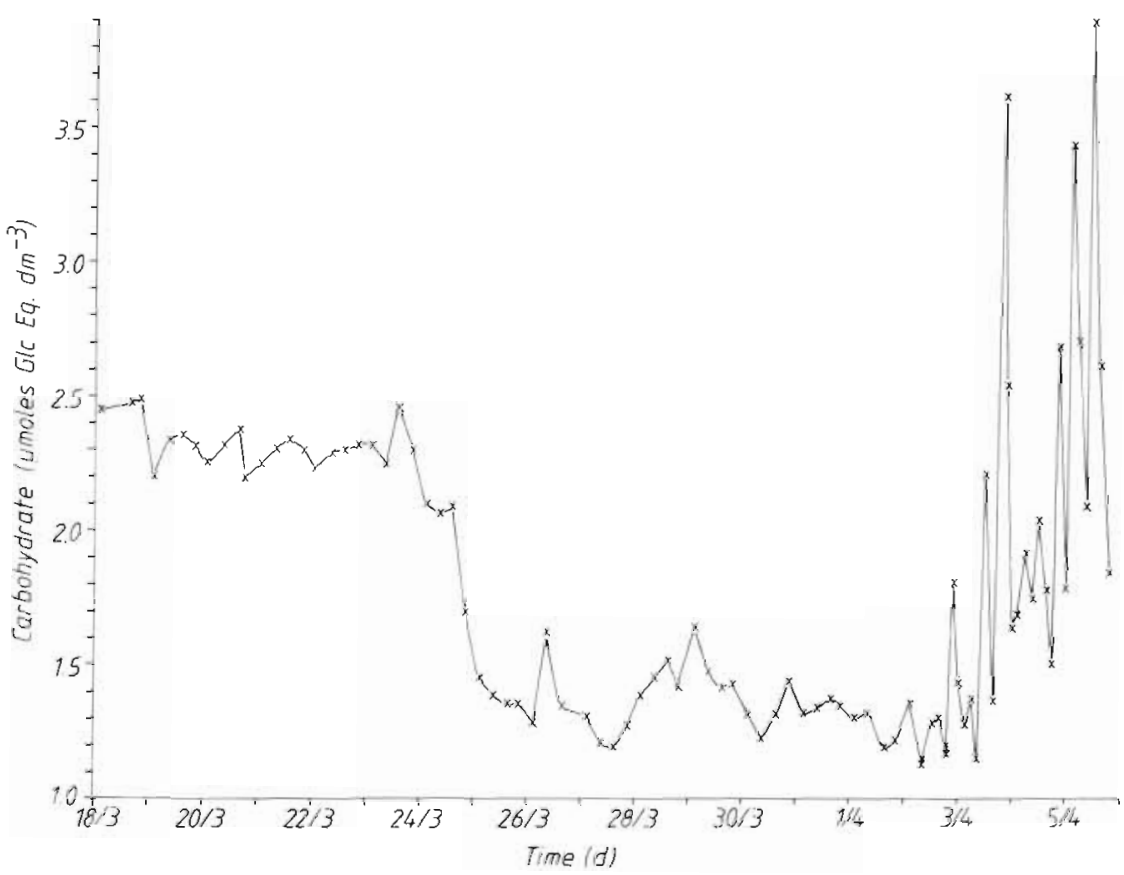

Fig. 8. Concentrations of total dissolved carbohydrates (measured as glucose equivalents) at $3 \mathrm{~m}$ in the Skeletonema tank 


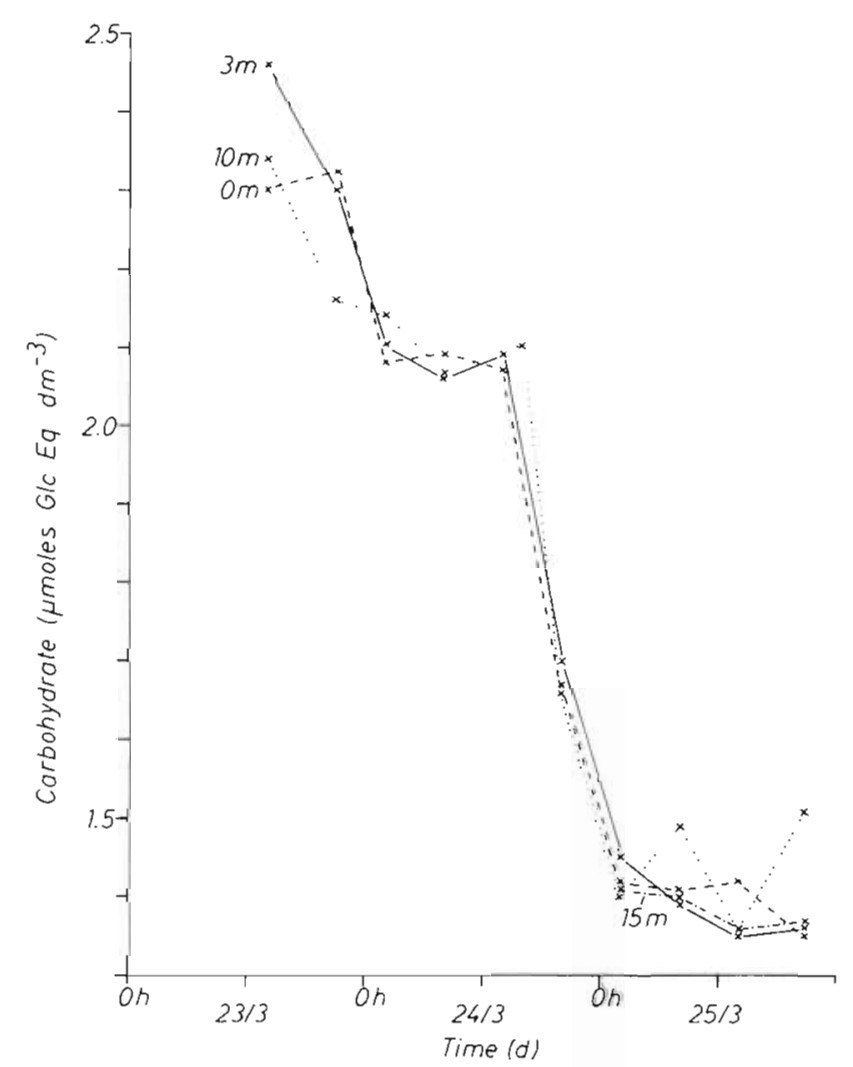

Fig. 9. Concentrations of total dissolved carbohydrates during period of high decrease, as in Fig. 8 but represented for different depths

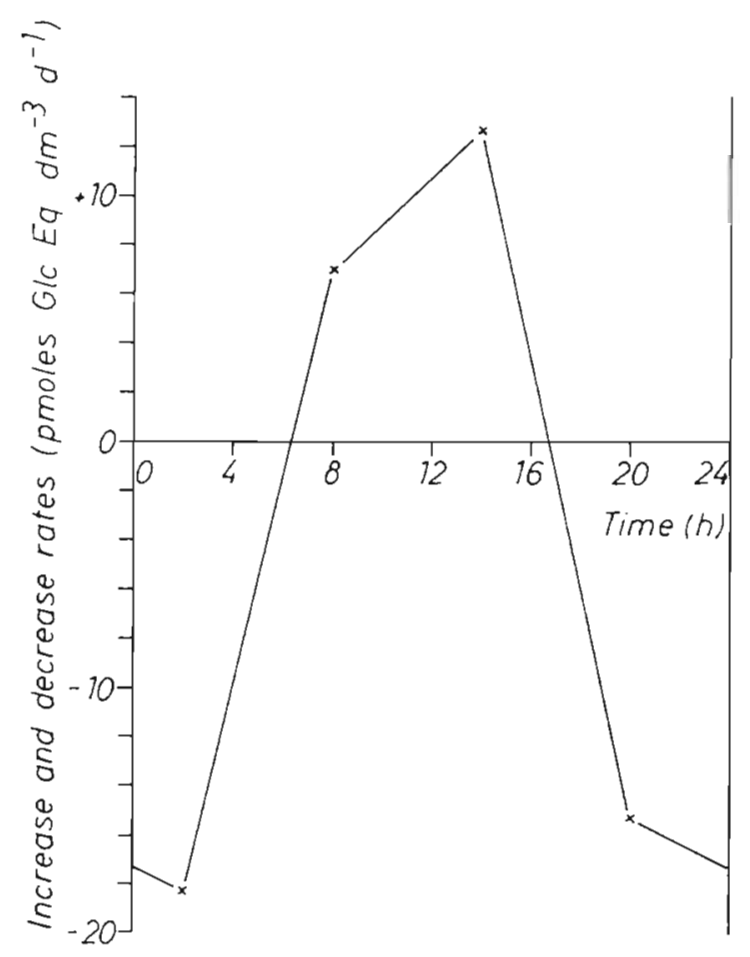

Fig. 10. Daily cycle of decrease and increase rates of total dissolved carbohydrates at $3 \mathrm{~m}$ in the Skeletonema tank, averaged data from March 19 to 23
Fig. 11. Concentrations of total dissolved carbohydrates during period of maximum cell numbers of Skeletonema costatum, as in Fig. 8 but represented for different depths

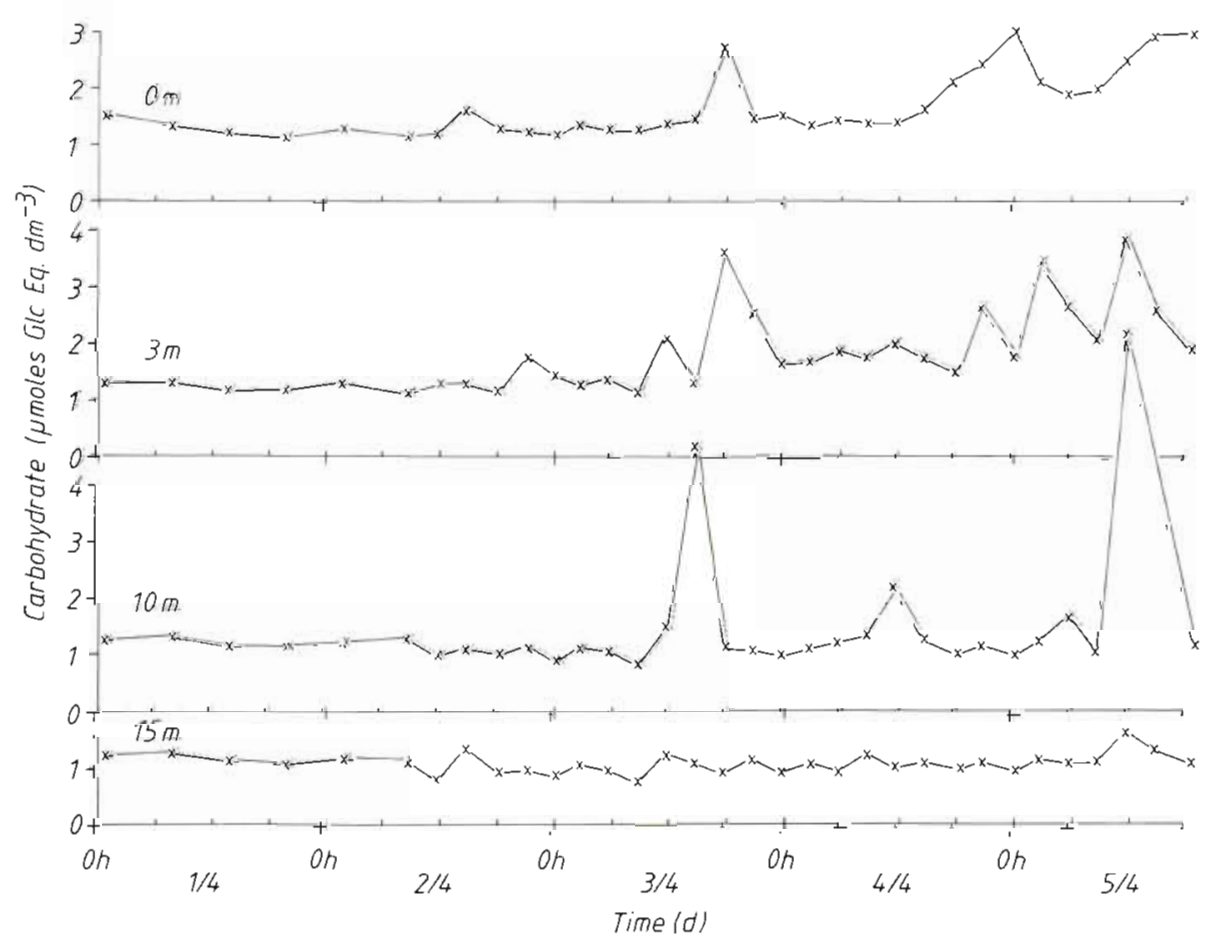




\section{DISCUSSION}

\section{Biological development in the enclosure}

\section{Growth of Skeletonema costatum}

Due to experimental conditions, the inoculated diatom Skeletonema costatum was not the only organism in the enclosure and grew slowly. Its low division rate of $\mu=0.6 \mathrm{~d}^{-1}$ was caused to some extent by the low temperatures $\left(1\right.$ to $\left.3^{\circ} \mathrm{C}\right)$; in the 1973 enclosure experiments with the same diatom, $\mu=2.1$ to $2.4 \mathrm{~d}^{-1}$ was found at 15.4 to $17.3^{\circ} \mathrm{C}$ (Brockmann et al., 1977a). These results are in good accordance with those obtained in laboratory cultures (Jørgensen, 1968; Eppley, 1972) indicating that laboratory investigations on variations in growth rate with temperature can be useful guides for field work.

Field observations revealed that Thalassiosira nordenskioeldii is usually the dominant early spring diatom at 2 to $3^{\circ} \mathrm{C}$. It is replaced by other species, such as Skeletonema costatum, when water temperatures rise (Guillard and Kilham, 1977). Some weeks before starting our culture experiment with $S$. costatum, relatively high numbers of this diatom were found in the Rosfjord at 5 to $6^{\circ} \mathrm{C}$. After March 8, S. costatum could scarcely be detected in fjord samples due to low light intensities and later because of decreasing water temperatures (Kattner et al., 1983). Nevertheless this diatom grew exponentially in our culture tank.

Taking Eppley's formula (Eppley, 1977) for computation of maximal growth rates, Skeletonema costatum should reach $\mu=1.0 \mathrm{~d}^{-1}$ at 1 to $3^{\circ} \mathrm{C}$, provided that other environmental factors were optimal. However, only 0.6 divisions $\mathrm{d}^{-1}$ were found. Concentrations of inorganic nutrients should be considered satisfactory due to fertilization at the beginning of the experiment. But light intensities were perhaps not high enough for optimal development of $S$. costatum due to the early season and to shading influences. This can be deduced from the delay of diatom development at $10 \mathrm{~m}$ (Fig. 1) and by comparison of nutrient uptake at different depths (Fig. 4 to 6): Nitrate, phosphate and silicate uptake was delayed with increasing depth. Comparison of the mean light intensity of $15 \mathrm{n}$ Einstein $\mathrm{cm}^{-2} \mathrm{~s}^{-1}$, measured at $5 \mathrm{~m}$ depth during the experiment (Brockmann et al., 1982), with saturating light intensities of 13 to $32 \mathrm{n}$ Einstein $\mathrm{cm}^{-2} \mathrm{~s}^{-1}$, determined in Iaboratory cultures of $S$. costatum at relatively high temperatures (Eppley, 1977), does not reveal whether light limitation was the decisive factor or not.

In spite of sub-optimal conditions, Skeletonema costatum reached high cell densities $\left(35 \cdot 10^{6} \mathrm{dm}^{-3}\right)$ in the enclosure, obviously because competing algae and grazing zooplankters were absent. Moreover, vertical water exchange was limited in the tank. The drop of cell numbers on April 1 to 2 at $3 \mathrm{~m}$ (Fig. 1) cannot be explained.

\section{Succession of organotrophic microorganisms}

Bacteria were limited in their development earlier than diatoms (Fig. 2). Maximum increase rates of AOTC and CFU were found from March 19 to 22, coinciding with increased ammonia at all sampling depths (Fig. 7). This suggests decomposition processes by heterotrophic bacteria (Sorokin, 1978) and remineralization of proteins, amino acids and other nitrogen-containing substances assumed to have resulted in high concentrations from an algal bloom in the fjord before the water for the tank experiment was enclosed (see also p. 53). Moreover, an amino-acid containing pre-culture medium had been added to the tank by re-inoculation with bacteria isolates on March 21. The decrease in ammonia concentrations from March 22 to 25 (Fig. 7) indicates that utilizable nitrogen-containing substances ran low due to consumption by bacteria.

In 1973 tank experiments with Skeletonema costatum, a rapid reduction in heterotrophic bacteria (CFU) was observed when the algal population reached $10^{6}$ cells $\mathrm{dm}^{-3}$. This was attributed to effects of bactericidic substances excreted by the diatoms (Brockmann et al., 1977 a). In the present experiment, however, an inhibitory effect of ciatoms on bacteria is considered to be of little importance for the interpretation of the biological development because of the low division rate of $S$. costatum. Moreover, both the total and the heterotrophic population of bacteria developed in very similarly at both depths sampled, while the growth of $S$. costatum was delayed $2 \mathrm{~d}$ at $10 \mathrm{~m}$ compared to $3 \mathrm{~m}$. No selective effect on the removal of any of the 5 strains counted by specific immunofluorescent staining was detected (Dahle and Laake, 1982), such as would be expected if bacteriolytic agents had been active.

A bacteriostatic effect cannot explain the rapid cell reduction observed in AOTC, since this method includes dead but morphologically intact cells, as well as dormant ones. A depletion of energy sources - e.g. available carbohydrates - although certainly governing bacterial growth rates and physiological state, cannot explain the rapid disappearance observed either. Bacterial aggregates were not frequently found in AOTC, and since there was no time lag in the disappearance of bacteria at $10 \mathrm{~m}$ compared to $3 \mathrm{~m}$, this reduction cannot be due to sedimentation.

Most likely, the observed effect of decreasing bacteria numbers was due to overgrazing by phagotrophic nanoflagellates, which in recent years have been ascribed the role as dominant grazers on bacteria in 
the sea (Seki, 1965; Lighthart, 1969; Sieburth et al., 1978; Haas and Webb, 1979; King et al., 1980). Other potential grazers on bacteria were not present in AOTC or phytoplankton samples. Unfortunately we did not examine nanoflagellate components microscopically in samples from this tank, but unidentified nanoflagellates were commonly present in the surrounding sea water at the time of this experiment (Brockmann et al., 1981); we have no other sound explanations for the rapid increase in the 1.5 to $3.0 \mu \mathrm{m}$ fraction of particles observed after March 23 (Fig. 3). Some families of nanoflagellates (Bodonidae, Amphinomadidae, Monadidae) have cell diameters within this range, and have been demonstrated to feed voraciously on marine bacteria in culture (Haas and Webb, 1979; Laake and Holm-Hansen, unpubl.).

If correct, our observations and assumptions would represent the first published evidence for actual grazing of bacteria by nanoflagellates in a planktonic system under natural conditions. On the basis of this interpretation, the flagellates overgrazed their food resource and reduced it rapidly to a bacterial density $\left(10^{8}\right.$ cells $\left.\mathrm{dm}^{-3}\right)$ where no net energy could be obtained, since bacterial production probably was rate-limited by the availability of energy sources during the steadystate phase, as shown later for total carbohydrates. The steady-state phase of bacteria (Fig. 2) must be considered a dynamic equilibrium between rapid bacterial cell production, based on dissolved carbohydrates and other energy sources, and rapid cell removal by grazing

The bacteria observed by epifluorescence microscopy were primarily small planktobacteria (Sieburth, 1979) with cell diameters from 0.4 to $0.6 \mu \mathrm{m}$, assumed to be most active in uptake of dissolved substrates (Hoppe, 1976; Azam and Hodson, 1977). However, also larger bacteria with diameters in the range of 0.7 to $0.9 \mu \mathrm{m}$ were present in significant numbers. These may be considered epibacteria (Sieburth, 1979) primarily associated with particulate substrates and dominating the CFU data. On March 28 CFU comprized ca. $10 \%$ of AOTC by numbers. A mean cell volume of $0.1 \mu \mathrm{m}^{3}$ in the AOTC population and $0.3 \mu \mathrm{m}^{3}$ in the CFU population was estimated. Assuming the observed maximum specific growth rate of $0.62 \mathrm{~d}^{-1}$ for the whole period of March 20 to 27 and taking into consideration a steadystate AOTC population of $2.2 \cdot 10^{9}$ cells $\mathrm{dm}^{-3}$, a maximum daily production potential of $1.4 \cdot 10^{9}$ cells $\mathrm{dm}^{-3}$ $\mathrm{d}^{-1}$ can be estimated. By assuming a bacterial biomass

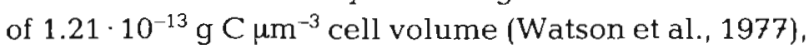
this equals $17 \cdot 10^{-6} \mathrm{~g} \mathrm{C} \mathrm{dm} \mathrm{dm}^{-3} \mathrm{~d}^{-1}$, which may be considered a rough estimate of the bacterial production potential during the period March 20 to 27 . On March 18 to 19 the potential production was in the order of $10^{-6} \mathrm{~g} \mathrm{C} \mathrm{dm}^{-3} \mathrm{~d}^{-1}$. From these estimates a maximum total bacterial production of about $140 \cdot 10^{-6} \mathrm{~g} \mathrm{C} \mathrm{dm}^{-3}$ is derived for the period March 18 to 27 .

Assuming a $30 \%$ efficiency in conversion of carbohydrates to bacterial biomass (Bell and Sakshaug, 1980), a bacterial production of $47.5 \cdot 10^{-6} \mathrm{~g} \mathrm{C} \mathrm{dm}^{-3}$ may result from an uptake of $2.2 \mu$ moles Glc Eq dm ${ }^{-3}$ (see below). By using ammonia release values in addition, the uptake of nitrogen-containing organic substances was estimated which were utilized by deaminating processes. Assuming a $\mathrm{C}: \mathrm{N}$ ratio of $7: 1$ for the nitrogencontaining substances (Hentzschel, pers. comm.), the release of $0.8 \mu$ moles ammonia $\mathrm{dm}^{-3}$ during the period March 19 to 22 indicates a bacterial production of $20.2 \cdot 10^{-6} \mathrm{~g} \mathrm{C} \mathrm{dm}^{-3}$. Both estimates lead to a possible bacterial production of $67.7 \cdot 10^{-6} \mathrm{~g} \mathrm{C} \mathrm{dm}^{-3}$, a value in the same range as that computed from bacterial counts.

The AOTC increase of $9.4 \cdot 10^{8}$ cells $\mathrm{dm}^{-3}$ (Fig. 2) during March 19 to 21 at $3 \mathrm{~m}$, corresponds to a production of $12 \cdot 10^{-6} \mathrm{~g} \mathrm{C}_{;} 80 \%$ of this can be attributed to the uptake of nitrogen-containing substances, indicated by a release of $0.37 \mu$ moles ammonia $\mathrm{dm}^{-3}$, whereas $70 \%$ of the supposed bacterial production from March 23 to 25 may be due to the uptake of dissolved carbohydrates amounting 1.1 moles Glc Eq $\mathrm{dm}^{-3}$ (see below).

Two to $3 \mathrm{~d}$ after the beginning of the increase in the 1.5 to $3 \mu \mathrm{m}$ particle numbers (Fig. 3), ammonia concentrations at all depths began a second increase (Fig. 7). The very high ammonia concentrations at the surface were probably not caused by contamination from outside, since ammonia concentrations at all depths increased during the period March 26 to 31. The cause for the second ammonia increase is unknown.

Diatoms obviously remained unaffected by the growth of bacteria and organotrophic flagellates; this is indicated by their division rate which remained constant during the whole experiment (Fig. 1).

\section{Uptake of inorganic nutrients}

Except for ammonia, the measurable uptake of inorganic nutrients by Skeletonema costatum was not influenced by the growth of bacteria and organotrophic flagellates (Fig. 4 to 6). Fluctuations of phosphate and nitrate rates prior to definite uptake lie within the limits of measurement errors ( \pm 0.05 and $\pm 0.3 \mu$ moles $\mathrm{dm}^{-3}$, respectively). Silicate measurements showed a smaller relative error $( \pm 0.05 \mu$ moles $\mathrm{dm}^{-3}$ ), therefore the increase after March 23 (Fig. 5) is indicative of a first small uptake.

Phosphate and nitrate were taken up in demonstrable quantities only after the diatom growth had reached the high rate of about $2 \cdot 10^{6}$ cells $d^{-1}$. At $3 \mathrm{~m}$ a 
final cell number of $35 \cdot 10^{6}$ diatoms $\mathrm{dm}^{-3}$ was obtained, not including burst or sedimented cells. Averaging uptake over the entire experiment gives values for mean nutrient consumption per $10^{6}$ cells of: 0.02 $\mu$ moles o-phosphate; $0.32 \mu$ moles nitrate; $0.21 \mu$ moles silicate.

Apart from the early phosphate consumption, phosphate and silicate were taken up simultaneously, while the uptake of nitrate was clearly retarded. There is a strong indication that nitrogen sources other than nitrate were used first. According to mean nutrient consumption values per $10^{6}$ cells, a diatom increase of $5.4 \cdot 10^{6}$ cells $\mathrm{dm}^{-3}$, which occurred at $3 \mathrm{~m}$ on March 30 to 31 , requires a nitrate uptake of $1.7 \mu$ moles $\mathrm{dm}^{-3}$. However, we recorded an uptake of only $0.3 \mu$ moles $\mathrm{dm}^{-3}$ for this period.

Measurable nitrate uptake at 0 and $3 \mathrm{~m}$ was obtained only after ammonia concentrations had fallen below $0.4 \mu$ moles $\mathrm{dm}^{-3}$. This means that ammonia was used by Skeletonema costatum before nitrate was taken up - a finding reported for marine phytoplankton by several investigators (for review see McCarthy, 1980). Consequently, our calculated N:P uptake ratio of 16 , resulting from the measured nitrate:phosphate uptake, is an underestimate, although it is in good accordance with Fleming (1940), Harris and Riley (1956) and Redfield (1958) who reported a ratio of 15-17:1 for phytoplankton. In our tank experiment cell composition should be roughly comparable with the uptake ratio due to the dominance of nutrient uptake by diatoms over other removal or release processes.

\section{Dynamics of total dissolved carbohydrates}

Initial carbohydrate concentrations

Relatively high initial concentrations of total dissolved carbohydrates $\left(2.3 \mu\right.$ moles $\mathrm{dm}^{-3}$, Fig. 8) were recorded in the filtered fjordwater enclosed after a diatom bloom, consisting largely of Thalassiosira nordenskioeldii, Thalassionema nitzschioides and Chaetoceros debilis (Brockmann et al., 1981; Jahnke et al., 1983; Kattner et al., 1983). The initial pool of dissolved carbohydrates may have consisted mainly of material originating in walls of dead cells. Because of the more complex composition of cell walls (Haug and Myklestad, 1976), their release products are believed to be less easily utilized than those from living cells. The possibility cannot be excluded that the initial high level of carbohydrate concentrations was caused in part by very small cell-wall fragments, passing $0.1 \mu \mathrm{m}$ filters and therefore being measured by the tryptophansulfuric acid-method.
Diurnal release of carbohydrates from March 18 to 24

The daily cycle computed for the relatively small fluctuations of carbohydrate concentrations during the first $6 d$ of the experiment (Fig. 10), can be explained by photosynthetically active organisms, such as Skeletonema costatum, releasing carbohydrates during daylight which were probably taken up again by heterotrophic organisms. Cell numbers of $S$. costatum increased from $5 \cdot 10^{4} \mathrm{dm}^{-3}$ to only $30 \cdot 10^{4} \mathrm{dm}^{-3}$ from March 18 to 23 (Fig. 1) and were perhaps a little too low to account for the relatively high carbohydrate release during this period. Possibly, the release of organic substances facilitated a continuous increase of diatom cell numbers by chelating trace metals or by promotion of bacteria which release vitamin $B_{12}$ required by Skeletonema costatum (Droop, 1955 , 1962).

A mean daily release rate of $0.2 \mu$ moles Glc Eq dm ${ }^{-3}$ was computed for the initial phase of the experiment at $3 \mathrm{~m}$. This is equivalent to 2.0 pmoles per cell, decreasing to 0.4 pmoles cel1 ${ }^{-1}$ with increasing cell numbers (29 to $144 \mathrm{pg} \mathrm{C} \mathrm{cell}{ }^{-1}$ ). For Skeletonema costatum with a mean cell size of $6 \times 9 \mu$ a carbon content of about $25 \mathrm{pg} \mathrm{cell}^{-1}$ was computed (Hagmeier, pers. comm.). If the diatoms were responsible for the increase in carbohydrate concentrations during daylight, they would have had to release 1.1 to 5.8 times their carbon content $\mathrm{d}^{-1}$ from March 18 to 23 . Since healthy algae can release more than $40 \%$ of their photosynthetic products (Lewin, 1956; Prager et al., 1959; Guillard and Hellebust, 1971; Ignatiades and Fogg, 1973), such high release rates of $S$. costatum do not seem to be impossible.

Algae species other than Skeletonema costatum could not have been responsible for the high carbohydrate release during daylight, because of their absence from microscopic samples. Coulter Counter data gave no hint that small green flagellates occurred in larger numbers during the time in question. The supposition that cell fragments of fjord algae, present in the enclosure in spite of pre-filtration, released the carbohydrates, is contradicted by the fact that the daily carbohydrate release rates remained constant over the period of $6 \mathrm{~d}$, whereas the activity of cell fragment enzymes is believed to diminish during such a long period.

The calculable release value for March 18 to 23 totals $1.1 \mu$ moles Glc Eq dm $\mathrm{dm}^{-3}$ at $3 \mathrm{~m}$ and represents a high energy potential. The consumers in question are the organotrophic bacteria which showed their highest increase rates in counts during this time (Fig. 2).

Attention should be drawn to the fact that during the night carbohydrate concentrations never fell to values lower than $2.2 \mu$ moles $\mathrm{dm}^{-3}$ (Fig. 8). The relatively 
small fraction of carbohydrates released during daylight, amounting at most to $12 \%$ of the total carbohydrates, showed a high tumover, whereas the large fraction of inert carbohydrates remained unchanged and constantly high.

Decrease of carbohydrate concentrations from March 23 to 24

The sudden, rapid decrease in carbohydrate concentrations from March 23 to 24 can be interpreted by assuming that bacteria, as a result of a succession of different species, or due to food limitation, adapted their enzyme systems to the degradation of complex and inert carbohydrates. Decreasing ammonia concentrations in the period March 23 to 25 (Fig. 7) indicate that carbohydrates were a main source of energy for organotrophic organisms, whereas free ammonia perhaps had to be used as a nitrogen source. Within $2 \mathrm{~d}$, at least $1.1 \mu$ moles $\mathrm{Glc} \mathrm{Eq} \mathrm{dm}{ }^{-3}$ were taken up, with similar rates at all depths (Fig. 9).

Organotrophy among non-pigmented flagellates has been demonstrated at high solute concentrations (Droop, 1970; Haas and Webb, 1979), but is not a thoroughly studied subject. Haas and Webb (1979) tested 5 bacteria-grazing species of nanoflagellates and were unable to demonstrate uptake of $11{ }^{14} \mathrm{C}$ labelled amino acids, carbohydrates and organic acids commonly present in sea water at concentrations far above their ambient levels. Considering the much lower surface to cell volume ratio, compared to bacteria, the generally wide spectrum of metabolic capabilities among bacteria, and their generally higher growth rates, the flagellates would seem to be non-competitive (Fenchel and Jørgensen, 1977). In our experiment, however, they may actively have removed carbohydrates by phagocytosis of particles, which, due to the filtration methods used, perhaps were included in the dissolved fraction. The rapid increase in 1.5 to $3 \mu \mathrm{m}$ particle numbers (Fig. 3) began exactly when carbohydrate concentrations fell (Fig. 8).

Low carbohydrate concentrations from March 24 to April 1

Utilization of the fraction of complex and stable carbohydrates terminated on March 25 and did not include all carbohydrates. Values lower than 1.1 to 1.2 $\mu$ moles Glc Eq dm${ }^{-3}$ were not measured during the whole experiment (Fig. 8) indicating a degradation limit, since the minimum concentration was reached within a short time and then remained constant.

The small fluctuations of carbohydrate concentra- tions shown in Fig. 8 for March 26 to April 1 cannot be interpreted as diurnal release. A combination of different processes must be assumed, e.g. release by growing diatoms and by different degradation processes, as well as uptake by heterotrophic organisms. In any case, a food limitation for organotrophic organisms is indicated for the whole period of March 26 to April 1 by the low carbohydrate concentrations.

High fluctuations of carbohydrate concentrations from April 1 to 5

The short-lived carbohydrate maxima in the period April 2 to 5, which were especially high during daylight or shortly after sunset, can only be attributed to release by photosynthetically active organisms such as Skeletonema costatum. The diatoms reached maximum cell numbers during this time, which was also when nutrients were exhausted. Similar fluctuations of release had been observed for amino acids and carbohydrates in 1973 tank experiments with cultures of Thalassiosira rotula (Hammer and Eberlein, 1981; Hammer et al., 1981; Eberlein, unpubl.).

Extremely high carbohydrate maxima at $10 \mathrm{~m}$ (Fig. 11), which appeared only at $12.00 \mathrm{~h}$ and $15.00 \mathrm{~h}$, point to a release by photosynthetically active organisms, due to a surplus production during maximum light intensities. Since such high carbohydrate maxima were not found in upper water depths, high release rates cannot be attributed to a damage of cells by too high light intensities.

Since each high release of carbohydrates was immediately followed by a rapid decrease in concentration, highly efficient uptake processes must be taken into account. The organisms in question are organotrophic bacteria and flagellates; their numbers increased again a little at the end of the experiment (Fig. 2 and 3), although adsorption to particles or reuptake of the released organic substances by the diatoms themselves cannot be excluded (Hellebust, 1970; Wheeler et al., 1974; Sepers, 1977; Lewin and Hellebust, 1978). Adsorption to tank walls is unlikely to occur so rapidly.

Carbohydrate release at different water depths (Fig. 11) was influenced by varying diatom development with depth, due to different light conditions. At $3 \mathrm{~m}$, the stationary phase was reached on April 3 (Fig. 1), when nutrients were used up (Fig. 4 to 6). At the surface, the stationary phase was reached $1 \mathrm{~d}$ earlier, as shown by nutrient uptake rates (Fig. 4 to 6 ), while nutrient concentrations at 10 and $15 \mathrm{~m}$ indicate that the stationary phase was not reached at all. Fig. 1 illustrates that the stationary phase at these depths did not begin before April 5 . 
The release of carbohydrates was different not only at different depths, but also during different growth phases. During exponential phase, background-level values of carbohydrate concentrations did not increase (Fig. 10,10 m). This means that the concentrations of the complex and stable carbohydrate fraction remained constant, whereas they increased during the stationary phase (Fig, 11,0 and $3 \mathrm{~m}$ ), probably due to senescence and decomposition of some of the diatom cells. As stated above, carbohydrates released from cell walls are more complex and less easily utilized than storage saccharides released by living cells.

On April 1, 2, and 4 no high carbohydrate release rates could be demonstrated at any depth. It is not clear whether this is due to environmental or internal factors.

The total quantity of released carbohydrates was extremely high at the end of the experiment; however only up to 0.2 pmoles cell ${ }^{-1} \mathrm{~d}^{-1}$ was released, which is less than 0.4 to 2.0 pmoles cell ${ }^{-1} \mathrm{~d}^{-1}$ at the beginning of the experiment. The methods used in this investigation did not allow a determination of carbohydrates taken up immediately after release. Their concentrations could have increased towards the end of the experiment and could be missing in the estimations, resulting in an underestimate of the total release per cell. It is possible that organotrophic bacteria were living directly on the surface of diatom cell walls taking up most of the liberated substances during exudation.

\section{CONCLUSIONS}

Dissolved carbohydrates in the enclosure experiment originated from different sources. One part was in the water by the beginning of the experiment, probably due to a phytoplankton bloom in the fjord before the test water was filtered and enclosed. Another part was released by growing Skeletonema costatum. The release per cell was initially extremely high, but maximum concentrations were released at the end of the exponential phase. During the course of a day, release activity changed strongly within a few hours. Main release occurred from noon to midnight.

At the start of the experiment, before succession or adaptation of bacteria began, the maximum portion of rapidly utilizable carbohydrates reached only $12 \%$ of total carbohydrates. At the end of the exponential phase of Skeletonema costatum, however, the maximum value of this fraction amounted to $82 \%$ (at $10 \mathrm{~m}$ ). During the stationary phase the labile portion of carbohydrates, which showed a high turnover, decreased again to a lower maximum value of $37 \%$ (at $0 \mathrm{~m}$ ). Obviously, organotrophic bacteria and perhaps other microorganisms may have utilized the dissolved car- bohydrates in a different way, according to their origin. Presumably, those carbohydrates were taken up immediately that were released by healthy cells during the exponential phase and at the beginning of the stationary phase. Carbohydrates only utilized after adaptation or succession of bacteria and those not taken up at all, originated probably from senescent and decomposing phytoplankton cells.

According to the different utilization types of carbohydrates, their concentrations decreased to 2 different ground levels. During the first $6 \mathrm{~d}$ of the experiment, when only those carbohydrates were consumed which were released in a daily cycle, a background level of $2.2 \mu$ moles Glc Eq $\mathrm{dm}^{-3}$ was reached by uptake processes. As a result of bacteria succession or adaptation a second background level of $1.2 \mu$ moles Glc Eq $\mathrm{dm}^{-3}$ was attained on March 27. Only at the end of the experiment did these background-level concentrations increase again slightly at 0 and $3 \mathrm{~m}$, probably due to senescence and decomposition processes at the beginning of the stationary phase of the diatoms.

We plan further work in order to obtain more information on the highly efficient uptake processes during enclosure. Efforts will also be directed at determining release and uptake rates of carbohydrates more exactly by employing other methods, and at finding out which events in diatom cell growth and metabolism caused the extremely high but short-term carbohydrate release maxima in the end of the exponential and the beginning of the stationary phase.

Acknowledgements. Thanks are due to Dr. J. Jahnke for providing the diatom monoculture and to Dr. G. Hentzschel for advice and bacteriological sampling, employing his special sampling system. For technical assistance we are grateful to I. Büns, A. B. Dahle, H. Fichtner, G. Kramm, R. Lucht, B. PukaB, C. Sartori, M. Schütt, P. H. Tse, G. Wichmann und H. Wierhake. S. Euteneuer und C. Price are acknowledged for linguistic consultations.

This work was supported by 'Deutsche Forschungsgemeinschaft' through 'Sonderforschungsbereich 94 Meeresforschung - Hamburg' and by the Norwegian Pollution Research und Monitoring Program, contract FOH 405

\section{LITERATURE CITED}

Aaronson, S. (1978). Excretion of organic matter by phytoplankton in vitro. Limnol. Oceanogr. 23: 838

Azam, F., Hodson, R. E. (1977). Size distribution and activity of marine microheterotrophs. Limnol. Oceanogr. 22: 492-501

Bell, W H., Sakshaug, E. (1980). Bacterial utilization of algal extracellular products. II. A. kinetic study on natural populations: the phycosphaere effect. Limnol. Oceanogr 25: 1021-1033

Bolze, A., Soeder, C. J. (1978). Konzentrationsänderungen der extrazellulären organischen Substanz bei Synchronkulturen von Scenedesmus acutus var alternans Hortob. Arch. Hydrobiol. 82: 142-154 
Brockmann, U. H., Eberlein, K., Hentzschel, G., Schöne, H. K. Siebers, D., Wandschneider, K., Weber, A. (1977a). Parallel plastic tank experiments with cultures of marine diatoms. Helgoländer wiss. Meeresunters. 30: 201-216

Brockmann, U. H., Eberlein, K., Hosumbek, P., Trageser, H., Maier-Reimer, E., Schöne, H. K., Junge, H. D. (1977b). The development of a natural plankton population in an outdoor tank with nutrient-poor water. I. Phytoplankton succession. Mar. Biol. 43: 1-17

Brockmann, U. H., Eberlein, K., Junge, H. D., Maier-Reimer, E., Siebers, D. (1979). The development of a natural plankton population in an outdoor tank with nutrient-poor sea water II. Changes in dissolved carbohydrates and amino acids. Mar. Ecol. Prog. Ser. 1: 283-291

Brockmann, U. H., Koltermann, K. P., Dahl, E., Dahle, A., Eberlein, K., Gaertner, A., Gassmann, G., Hammer, K. D., Jahnke, J., Kattner, G., Krause, M., Kuiper, J., Laake, M., Nagel, K. (1981). Water exchange in Rosfjorden during spring 79 , a detailed account of physical, chemical and biological variations. In: Saetre, R., Mork, M. (ed.) The Norwegian coastal current. University Bergen, p. 93-130

Brockmann, U. H., Kattner, G., Hammer, K. D., Eberlein, K. (1982). General methods and physical measurements of POSER. Ber. SFB 94, Universität Hamburg 21: 21-40

Brockmann, U. H., Hentzschel, G. (1983). Samplers for enclosed stratified water columns. Mar. Ecol. Prog. Ser. 14: 107-109

Brockmann, U. H., Dahl, E., Kuiper, J., Kattner, G. (1983). The concept of POSER (Plankton observations with simultaneous enclosures in Rosfjorden). Mar. Ecol. Prog. Ser. 14: 1-8

Carlberg, S. R. (1972). New Baltic manual. ICES Cooperative Research Report, Ser. A, No. 29: 37-90

Dahle, A. B., Laake, M. (1982). Diversity dynamics of marine bacteria studied by immunofluorescence staining on membrane filters. Appl. environ. Microbiol. 43: 169-176

Degens, E. T. (1970). Molecular nature of nitrogenous compounds in sea water and recent marine sediments. In Hood, D. W (ed.) Organic matter in natural waters. Inst. Mar Sci., Alaska, p. 77-106

Droop, M. R. (1955). A pelagic marine diatom requiring cobalamin. J. mar. biol. Ass. U. K. 34: 229-331

Droop, M. R. (1962). Organic micronutrients. In: Lewin, R. A (ed.) Physiology and biochemistry of algae. Academic Press, New York, p. 141-159

Droop, M. R. (1970). Nutritional investigations of phagotrophic protozoa under axenic conditions. Helgoländer wiss. Meeresunters. 20: 272-277

Eberlein, K., Hammer, K. D. (1980). Automatic determination of total carbohydrates in sea water. Fresenius Z. Anal. Chem. 301: 17-19

Enzinger, R. M., Cooper, R. C. (1976). Role of bacteria and protozoa in the removal of Escherichia coli from estuarine waters. Appl. environ. Microbiol. 31: 758-763

Eppley, R. W. (1972). Temperature and phytoplankton growth in the sea. Fish. Bull. U. S. 70: 1063-1085

Eppley, R. W. (1977). The growth and culture of diatoms. In Werner, D. (ed.) The biology of diatoms. Blackwell Scientific Publications, Oxford, p. 24-64

Fenchel, T. M., Jørgensen, B. B. (1977). Detritus food chains of aquatic ecosystems: the role of bacteria. In: Alexander, $M$. (ed.) Advances of microbial ecology, Vol. I. Rosswall, New York, p. 1-58

Fleming, R. H. (1940). The compositon of plankton and units for reporting populations and production. Proc. sixth Pacif. Sci. Congr. Calif. 3: 535-540

Guillard, R. R. L., Hellebust, J. A. (1971). Growth and the production of extracellular substances by two strains of
Phaeocystis poucheti. J. Phycol. 7: 330-338

Guillard, R. R. L., Kilham, P. (1977). The ecology of marine planktonic diatoms. In: Wemer, D. (ed.) The biology of diatoms. Blackwell Scientific Publications, Oxford, p. $372-469$

Haas, L. W., Webb, K. L. (1979). Nutritional mode of several non-pigmented microflagellates from the York River estuary, Virginia. J. exp. mar Biol. Ecol. 39: 125-134

Hagström, §., Larsson, U., Hörstedt, P., Nordmark, S. (1979). Frequency of dividing cells, a new approach to the determination of bacterial growth rates in aquatic environments. Appl. environ. Microbiol. 37: 805-812

Hammer, K. D., Eberlein, K. (1981). Parallel experiments with Thalassiosira rotula in outdoor plastic tanks: development of dissolved free amino acids during an algae bloom. Mar. Chem. 10: 533-544

Hammer, K. D., Brockmann, U. H., Kattner, G. (1981). Release of dissolved free amino acids during a bloom of Thalassiosira rotula. Kieler Meeresforsch., Sonderh. 5: 101-109

Handa, N. (1970). Dissolved and particulate carbohydrates. In: Hood, D. W. (ed.) Organic matter in natural waters. Inst. Mar. Sci., Alaska, p. 129-152

Harris, E., Riley, G. A. (1956). Oceanography of Long Island Sound, 1952-1954. VIII. Chemical composition of the plankton. Bull. Bingham. oceanogr. Coll. 15: 315-323

Haug, A., Myklestad, S. (1976). Polysaccharides of marine diatoms with special reference to Chaetoceros species. Mar Biol. 34: 217-222

Hellebust, J. A. (1970). The uptake and utilization of organic substances by marine phytoplankters. In: Hood, D. W. (ed.) Organic matter in natural waters. Inst. Mar. Sci., Alaska, p. 225-256

Hellebust, J. A. (1974), Extracellular products. In: Stewart W. D. P. (ed.) Algal physiology and biochemistry. Blackwell Scientific Publications, Oxford, p. 838-863

Hobbie, J. E., Daley, R. J., Jasper, S. (1977). Use of Nuclepore filters for counting bacteria by fluorescence microscopy. Appl environ. Microbiol. 33: 1125-1228

Hoppe, H. G. (1976). Determination and properties of actively metabolizing heterotrophic bacteria in the sea, investigated by means of micro-autoradiography. Mar Biol. 36: 291-302

Ignatiades, L., Fogg, G. E. (1973). Studies on the factors affecting the release of organic matter by Skeletonema costatum (Greville) Cleve in culture. J mar. biol. Ass. U. K. 53: $937-956$

Jahnke, J., Brockmann, U. H., Aletsee, L., Hammer, K. D. (1983). Phytoplankton activity in enclosed and free marine ecosystems in a southern Norwegian fjord during spring 1979. Mar. Ecol. Prog. Ser 14: 19-28

Jergensen, E. G. (1968). The adaptation of plankton algae. II. Aspects of the temperature adaptation of Skeletonema costatum. Physiologia Pl. 21: 423-427

Kattner, G., Hammer, K. D., Eberlein, K., Brockmann, U. H., Jahnke, J., Krause, M. (1983). Nutrient and plankton development in Rosfjorden and enclosed ecosystems captured from changing water bodies during POSER. Mar. Ecol. Prog. Ser.14: 29-43

King, K. R. Hollibaugh, J. T., Azam, F. (1980). Predator-prey interactions between a larvacean, Oikopleura dioica, and bacterioplankton in enclosed water columns. Mar. Biol. 56: $49-57$

Lewin, R. A. (1956). Extracellular polysaccharides of green algae. Can. J. Microbiol. 2: 665-672

Lewin, J., Hellebust, J. A. (1978). Utilization of glutamate and glucose for heterotrophic growth by the marine pennate diatom, Nitzschia laevis. Mar. Biol. 47: 1-7 
Lighthart, B. (1969). Planktonic and benthic bacteriovorous protozoa at eleven stations in Puget Sound and adjacent Pacific Ocean. J. Fish. Res. Bd Can. 26: 299-304

Mague, T. H., Friberg, E., Hughes, D. J., Morris, I. (1980). Extracellular release of carbon by marine phytoplankton; a physiological approach. Limnol. Oceanogr. 25: 262-279

McCarthy, J. J. (1980). Nitrogen. In: Morris, I. (ed.) The physiological ecology of phytoplankton. Blackwell Scientific Publications, Oxford, p. 191-233

Prager, J. C., Burke, J. M., Marchisotto, J., McLaughlin, J. J. A. (1959). Mass culture of a tropical dinoflagellate and the chromatographic analysis of extracellular polysaccharides. J. Protozool. 6 (Suppl.): 19-20

Redfield, A. C. (1958). The biological control of chemical factors in the environment. Am. Scient. 46: 205-221

Seki, H. (1965). Studies on microbial participation of food cycle in the sea. II. J. oceanogr. Soc. Japan 20: 24-31

Sepers, A. B. J. (1977). The utilization of dissolved organic compounds in aquatic environments. Hydrobiologica 52 : 39-54

Sharp, J. H. (1978). Reply to comment by S. Aaronson. Limnol.
Oceanogr 23: 839-840

Sieburth, J. McN. (1968). The influences of algal antibiosis on the ecology of marine microorganisms. In: Droop, M. R., Ferguson-Wood, E. J. (ed.) Advances in microbiology of the sea. Academic Press, New York, p. 63-94

Sieburth, J. McN. (1979). Sea microbes. Oxford University Press, New York, p. 241-245

Sieburth, J. McN., Smetacek, V., Lenz, J. (1978). Pelagic ecosystem structure: heterotrophic compartments of the plankton and their relationship to plankton size fractions. Limnol. Oceanogr. 23: 1256-1263

Sorokin, Y. I. (1978). Decomposition of organic matter and nutrient regeneration. In: Kinne, $\mathrm{O}$. (ed.) Marine ecology, Volume IV, Dynamics. Wiley, Chichester, p. 501-616

Watson, S. W., Novitsky, T. J., Quinby, H. L., Valois, F. W (1977). Determination of bacterial numbers and biomass in the marine environment. Appl. environ. Microbiol. 33: 940-946

Wheeler, P. A., North, B. B., Stephens, G. C. (1974). Amino acid uptake by marine phytoplankters. Limnol. Oceanogr. 19: $249-259$

This paper was submitted to the editor; it was accepted for printing on July 29, 1983 